\title{
Prostate Cancer Clinical TNM Finding v6
}

National Cancer Institute

\section{Source}

National Cancer Institute. Prostate Cancer Clinical TNM Finding v6. NCI Thesaurus. Code C48893.

A clinical finding about one or more characteristics of prostate cancer, following the rules of the TNM AJCC v6 classification system. TNM clinical findings are based on information obtained prior to the first definitive treatment through physical examination, diagnostic imaging, endoscopy, biopsy or laboratory testing. 